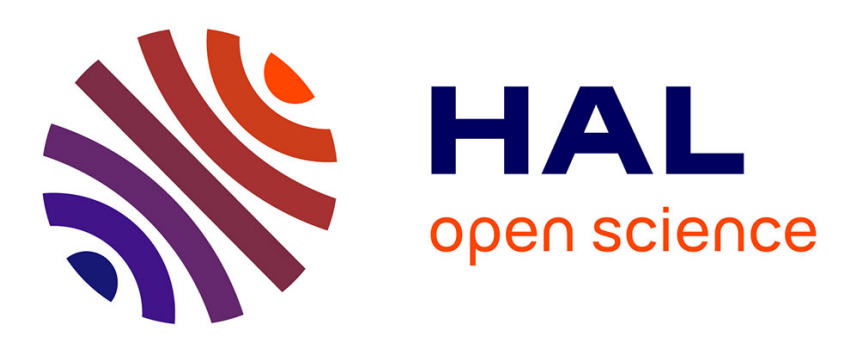

\title{
Morpho-chronological variations and primary production in Posidonia sea grass from Western Australia
}

Gérard Pergent, Christine Pergent-Martini, Catherine Fernandez, Pasqualini Vanina, Diana Walker

\section{- To cite this version:}

Gérard Pergent, Christine Pergent-Martini, Catherine Fernandez, Pasqualini Vanina, Diana Walker. Morpho-chronological variations and primary production in Posidonia sea grass from Western Australia. Journal of the Marine Biological Association of the UK, 2004, 84 (5), pp.895-899. 10.1017/S0025315404010161h . hal-01768985

\section{HAL Id: hal-01768985 \\ https://hal.science/hal-01768985}

Submitted on 17 Apr 2018

HAL is a multi-disciplinary open access archive for the deposit and dissemination of scientific research documents, whether they are published or not. The documents may come from teaching and research institutions in France or abroad, or from public or private research centers.
L'archive ouverte pluridisciplinaire HAL, est destinée au dépôt et à la diffusion de documents scientifiques de niveau recherche, publiés ou non, émanant des établissements d'enseignement et de recherche français ou étrangers, des laboratoires publics ou privés. 


\title{
Morpho-chronological variations and primary production in Posidonia sea grass from Western Australia
}

\author{
Gérard Pergent* ${ }^{\ddagger}$, Christine Pergent-Martini*, Catherine Fernandez*, \\ Vanina Pasqualini* and Diana Walker ${ }^{\dagger}$ \\ *Equipe Ecosystèmes Littoraux, Faculty of Sciences, University of Corsica, BP 52, 20250 Corte, France. ${ }^{\dagger}$ Department of Botany, \\ University of Western Australia, Nedlands, Perth, Western Australia 6907. ${ }^{\ddagger}$ Corresponding author, e-mail: pergent@univ-corse.fr
}

\begin{abstract}
The occurrence of morpho-chronological variations was demonstrated in three Australian species of phanerogams, Posidonia australis, Posidonia coriacea and Posidonia sinuosa, which are found living around Rottnest Island (Western Australia). Three chronological parameters were identified: the thickness of dead sheaths, the internodal distance and the regular presence of floral stalk remains. The foliar primary production for these three species, as estimated using the lepidochronology method, is very high since values of 1374, 1811 and $678 \mathrm{mg} \mathrm{dw}$ shoot $^{-1} \mathrm{y}^{-1}$ were recorded, respectively. Rhizome production values range from 70.6 and $376.7 \mathrm{mg} \mathrm{dw}$ shoot $^{-1} \mathrm{y}^{-1}$ for Posidonia coriacea and Posidonia australis respectively. The results obtained are very encouraging and confirm that these morpho-chronological variations are particularly well developed for the genus Posidonia.
\end{abstract}

\section{INTRODUCTION}

Some living organisms exhibit morphological variations over time, usually induced by seasonal changes in environmental factors (i.e. temperature, precipitation). On land, the presence of annual growth rings in trees has led to the scientific field of dendochronology. Developments in this field have given rise to a wide range of applications, most notably the reconstitution of previous environments (i.e. palaeoclimatology). In the marine environment, morphological and anatomical characteristics have also been uncovered in the calcified structures of numerous organisms: for instance molluscs, Echinodermata, and fish.

The first detailed studies showing similar morphochronological variations in marine plants dealt with two Mediterranean sea grasses: Posidonia oceanica (L.) Delile (Crouzet et al., 1983) and Cymodocea nodosa (Ucria) Ascherson (Duarte \& Sand-Jensen, 1990). Preliminary studies had already made it possible to determine the age of rhizomes in Zostera marina Linnaeus (Petersen, 1913) and Thalassia testudinum Banks ex König (Patriquin, 1973). To date, the studies carried out in this field have primarily dealt with Posidonia oceanica (see review in PergentMartini \& Pergent, 1995), Zostera marina (Olesen \& SandJensen, 1993), and Thalassia testudinum (Marbà et al., 1994). Nevertheless, Syringogium filiforme Kutz. and Halodule wrighti Aschers were also tested. Most of these studies are based on the thickness of dead leaf sheaths, which remain along the rhizome after the blades have been shed. Monitoring the thickness of these sheaths, based on their insertion rank, provides evidence of marked cyclical variations with a very distinct and significant chronology (one cycle $=$ one year). The study of these variations over time is known as lepidochronology (Figure 1). The demonstration of these chronological variations rests upon the excellent preservation of dead sheaths within the matte, which may provide chronological sequences over periods between 15 and 50 years (Pergent et al., 1989). For Posidonia oceanica beds of the Mediterranean, the careful collection of these data has made a variety of applications possible, ranging from the study of growth dynamics, to human pressures (Pergent-Martini \& Pergent, 1995).

The main application of lepidochronology, however, involves a new method of estimating sea grass bed primary production. As compared with the more classical techniques such as leaf marking, oxygen evolution and ${ }^{14} \mathrm{C}$ fixation (Hillman et al., 1989), the lepidochronology method has the advantage of being accurate and all of the plant tissues can be taken into account (PergentMartini et al., 1994). A feasibility study was conducted, in January 1996, to study the application of this method to several species of Posidonia along the Australian coast (Pergent et al., 1997).

The aim of this study was therefore: (i) to characterize morphological parameters of shoots (phenology); (ii) to define the morpho-chronological cycles (periodicity, amplitude), rhizome growth and flowering periodicity; and (iii) to estimate more precisely the primary production using the lepidochronology method in three Australian species of Posidonia.

\section{MATERIALS AND METHODS}

Thirty shoots of each Posidonia species (Posidonia australis Hook. f., Posidonia sinuosa Cambridge \& Kuo, Posidonia coriacea Cambridge \& Kuo) were sampled in summer (January) and in winter (August), by SCUBA diving, around the island of Rottnest $\left(32^{\circ} 00 \mathrm{~S} 115^{\circ} 30 \mathrm{E}\right.$ - Western Australia), at depths of between 2 and $10 \mathrm{~m}$.

The leaves were stripped from each shoot in distichous order of insertion of the leaves. For each leaf, the total 


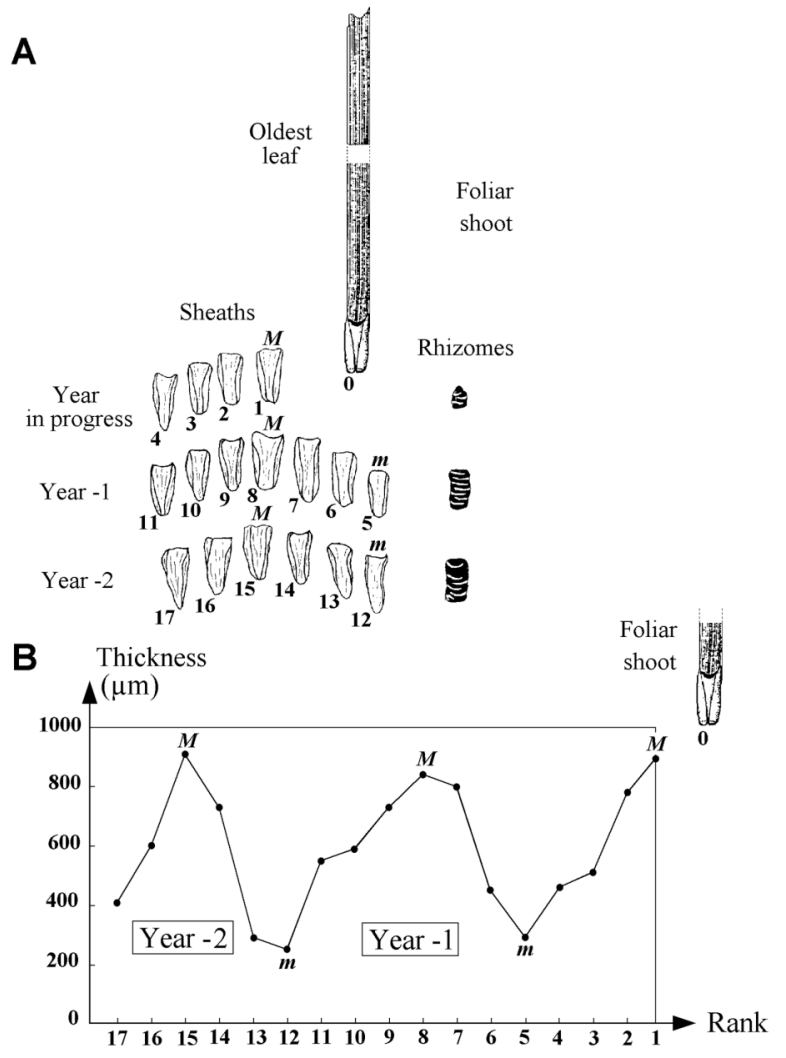

Figure 1. Dissection of Posidonia shoot using (A) the lepidochronological technique and (B) evolution of sheath thickness according to the insertion rank. M, sheath of maximum thickness; $\mathrm{m}$, sheath of minimum thickness (according to Pergent et al., 1997). length and width of the blade was measured as was the length of the sheath when present (adult leaf in Giraud, 1979). The percentage of leaves having lost their apex (due to the grazing of herbivores or to hydrodynamics) was recorded (=Coefficient A in Giraud, 1979). The foliar surface, corresponding to the surface area of all the leaves of a shoot, was also calculated.

For each rhizome, dead sheaths were carefully detached and numbered starting with the older ones (near the base) and finishing with the more recent ones (nearest to the living leaves). The thickness of each sheath was measured under a microscope (cross section), with an accuracy of $10 \mu \mathrm{m}$. The location of the flower stalk remains and the associated prophyll, inserted between sheaths, was noted. For each rhizome, the internodal distance was also measured (precision $= \pm 0.5 \mathrm{~mm}$ ).

The leaves of rank 1, that is to say the oldest (whose growth is finished), were scraped with a razor blade to remove epiphytes, placed at $70^{\circ} \mathrm{C}$ to constant weight and weighed (accuracy $0.1 \mathrm{mg}$ ) after separation of the blade and sheath. Rhizome segments corresponding to a oneyear period, as determined by the distance between each pair of sheaths of minimum thickness (Pergent et al., 1997), were measured. Primary production (PI) was estimated by the lepidochronology method on the basis of three parameters: (i) mean number of leaves produced annually (number of sheaths per cycle); (ii) mean length of leaf tissue (blades=BL and sheaths $=\mathrm{SL}$ ); and (iii) mean leaf tissue density (blades=BD and sheaths $=$ SD), which corresponds to leaf weight per unit length (Sand-Jensen, 1975):

Table 1. Main phenological parameters of three species of Posidonia sampled around Rottnest Island (interval of confidence at $95 \%)$.

\begin{tabular}{|c|c|c|c|}
\hline & P. australis & P. coriacea & P. sinuosa \\
\hline \multicolumn{4}{|c|}{ Number of adult leaves } \\
\hline -January & $2.1 \pm 0.2$ & $1.1 \pm 0.2$ & $0.7 \pm 0.2$ \\
\hline - August & $1.3 \pm 0.2$ & $0.6 \pm 0.1$ & $0.6 \pm 0.3$ \\
\hline \multicolumn{4}{|c|}{ Length of adult leaves (mm) } \\
\hline -January & $370.0 \pm 45.2$ & $798.1 \pm 56.7$ & $688.4 \pm 50.6$ \\
\hline —August & $237.5 \pm 18.2$ & $552.4 \pm 31.7$ & $203.9 \pm 45.8$ \\
\hline \multicolumn{4}{|c|}{ Length of leaf sheath (mm) } \\
\hline -January & $56.1 \pm 9.4$ & $102.4 \pm 11.7$ & $51.8 \pm 11.3$ \\
\hline - August & $47.8 \pm 3.4$ & $90.3 \pm 5.5$ & $36.4 \pm 12.1$ \\
\hline \multicolumn{4}{|c|}{ Width of adult leaves ( $\mathrm{mm}$ ) } \\
\hline -January & $12.2 \pm 0.6$ & $4.5 \pm 0.2$ & $7.6 \pm 0.3$ \\
\hline - August & $12.8 \pm 0.9$ & $3.9 \pm 0.1$ & $6.0 \pm 0.1$ \\
\hline \multicolumn{4}{|c|}{ Number of intermediate leaves } \\
\hline —January & $1.0 \pm 0.1$ & $1.1 \pm 0.1$ & $0.9 \pm 0.2$ \\
\hline - August & $1.0 \pm 0.2$ & $1.1 \pm 0.1$ & $1.0 \pm 0.3$ \\
\hline \multicolumn{4}{|c|}{ Length of intermediate leaves (mm) } \\
\hline -January & $120.5 \pm 14.9$ & $323.6 \pm 65.0$ & $419 \pm 78.0$ \\
\hline - August & $119.7 \pm 11.9$ & $297.5 \pm 19.1$ & $173.5 \pm 62.8$ \\
\hline \multicolumn{4}{|c|}{ Width of intermediate leaves ( $\mathrm{mm}$ ) } \\
\hline -January & $12.1 \pm 0.6$ & $4.6 \pm 0.2$ & $7.7 \pm 0.2$ \\
\hline -August & $12.6 \pm 0.9$ & $3.5 \pm 0.1$ & $5.8 \pm 0.3$ \\
\hline \multicolumn{4}{|c|}{ Coefficient A per shoot (\%) } \\
\hline -January & 10.8 & 5.6 & 26.7 \\
\hline - August & 8.3 & 24.2 & 34.8 \\
\hline \multicolumn{4}{|c|}{ Foliar surface $\left(\mathrm{cm}^{2}\right.$ shoot $\left.^{-1}\right)$} \\
\hline -January & $107.0 \pm 15.5$ & $59.7 \pm 9.3$ & $66.9 \pm 8.5$ \\
\hline -August & $53.9 \pm 7.3$ & $23.3 \pm 1.5$ & $17.9 \pm 4.2$ \\
\hline
\end{tabular}


Table 2. (A) Examples of thickness ( $\mu \mathrm{m})$ of the leaf sheaths of Posidonia sinuosa along several rhizomes, sampled in Fanuary and August. (B) Mean rank of maximum and minimum. Underlined numbers, minimum thickness; bold numbers, maximum thickness.

A.

\begin{tabular}{|c|c|c|c|c|c|c|c|c|c|c|}
\hline \multirow[b]{2}{*}{ Rank } & \multicolumn{5}{|c|}{ January } & \multicolumn{5}{|c|}{ August } \\
\hline & Rh. 1 & Rh. 2 & Rh. 3 & Rh. 4 & Rh. 5 & Rh. 1 & Rh. 2 & Rh. 3 & Rh. 4 & Rh. 5 \\
\hline 1 & 950 & 860 & 938 & 863 & 780 & 855 & 960 & 645 & 960 & 705 \\
\hline 2 & 920 & 903 & 1003 & 865 & 845 & 785 & 905 & $\overline{935}$ & $\overline{975}$ & $\overline{815}$ \\
\hline 3 & 970 & 785 & 1090 & 750 & 750 & $\overline{810}$ & $\overline{975}$ & 935 & 985 & 885 \\
\hline 4 & 865 & 848 & 1085 & 778 & 735 & 810 & 945 & 1015 & 990 & 875 \\
\hline 5 & 755 & 700 & 875 & 713 & 660 & 855 & 1010 & 905 & 965 & 805 \\
\hline 6 & 795 & 910 & 890 & 785 & $\frac{670}{670}$ & 855 & 950 & 900 & 850 & 795 \\
\hline 7 & 810 & 785 & 953 & 790 & 815 & 485 & 890 & $\frac{700}{910}$ & 410 & 790 \\
\hline 8 & 925 & 830 & 850 & 825 & 725 & $\frac{10}{775}$ & $\frac{075}{905}$ & 985 & $\frac{105}{905}$ & 855 \\
\hline 9 & 820 & 860 & 798 & 780 & 540 & 900 & 910 & 555 & 970 & 845 \\
\hline 10 & $1 \overline{040}$ & 680 & $\overline{983}$ & 525 & $\overline{555}$ & 835 & 860 & 1125 & 865 & 890 \\
\hline 11 & 1000 & $\overline{740}$ & 925 & $\overline{873}$ & 545 & 845 & 840 & & 900 & 935 \\
\hline 12 & 1085 & 978 & 1023 & 715 & 650 & 460 & $\overline{970}$ & & 800 & 890 \\
\hline 13 & 860 & 903 & 890 & 625 & 555 & & 930 & & & 830 \\
\hline 14 & 980 & 850 & 693 & 695 & 625 & & & & & $\overline{855}$ \\
\hline
\end{tabular}

B.

\begin{tabular}{lcr}
\hline & January & August \\
\hline Minimum 0 & - & $\underline{4.2}$ \\
Maximum 1 & $\mathbf{2 . 4}$ & $\underline{\mathbf{4 . 0}}$ \\
Minimum 1 & $\underline{5.0}$ & $\mathbf{9 . 6}$ \\
Maximum 2 & $\mathbf{7 . 2}$ & $\underline{12.0}$ \\
Minimum 2 & $\underline{9.4}$ & - \\
Maximum 3 & $\mathbf{1 1 . 8}$ & \\
\hline
\end{tabular}

Table 3. Morphological parameters showing chronological variations in different Posidonia species and mean periodicity of the cycles.

\begin{tabular}{|c|c|c|c|c|}
\hline & P. australis & P. coriacea & $P$. sinuosa & P. oceanica \\
\hline Number of sheath per cycle & $7.6 \pm 0.6$ & $5.1 \pm 0.9$ & $4.4 \pm 0.4$ & $7.2 *$ \\
\hline Number of leaf scars between two short internodes & $8.2 \pm 0.9$ & $6.0 \pm 0.9$ & $4.1 \pm 0.7$ & - \\
\hline Rank of florescence scars & 6.8 & 5.8 & - & - \\
\hline Mean periodicity & 7.5 & 5.6 & 4.3 & 7.2 \\
\hline
\end{tabular}

*, Mean for 22 Mediterranean sites (in Pergent-Martini et al., 1994); —, no data available; \pm interval of confidence at 95\%.

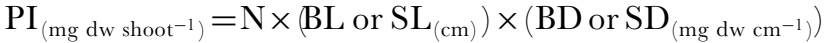

Foliar production was sub-divided into blade and sheath production by using the length and density of these tissues, respectively.

\section{RESULTS}

The structure of the leaf shoots, the foliar biometry and the characteristic parameters were measured for the three species of Posidonia studied (Table 1). Contrary to Posidonia oceanica, for which thickness of the leaf sheath is relatively constant, the leaf sheath thickness in Australian species decreases at a regular rate from the base (affixed to the rhizome) to the extremity. As for Posidonia oceanica, this thickness, however, appears to be relatively constant between 10 and $20 \mathrm{~mm}$ from the base. As a result, measurements were taken from this part of the sheath.

Rhizomes sampled in both January and August from each species showed cyclical changes in sheath thickness along the rhizomes (Table 2). These cycles are not as regular as those of Posidonia oceanica, and their amplitude is not as great. Nonetheless, as with the Mediterranean species, they appear to be synchronous for a given season. Mean rank for the minimum and maximum dead sheath thickness varies between January and August, which corresponds to the shedding of the old blades over time. Thus, as is observed for Posidonia oceanica in the Mediterranean, it is during the winter that the dead sheaths of Posidonia sinuosa exhibit their minimum thickness (Table 2). For Posidonia australis, the mean rank of the first minimum thickness 
Table 4. Shoot primary production of three species of Posidonia from Rottnest Island (Western Australia), using the lepidochronology method. *, the leaf number corresponds to mean periodicity of cycles (Table 3).

\begin{tabular}{|c|c|c|c|c|}
\hline & Leaf number* & Leaf length $(\mathrm{cm})$ & $\begin{array}{l}\text { Leaf density } \\
\left(\mathrm{mg} \mathrm{cm}^{-1}\right)\end{array}$ & $\begin{array}{c}\text { Production } \\
\mathrm{mg} \mathrm{dw} \operatorname{shoot}^{-1} \mathrm{y}^{-1}\end{array}$ \\
\hline \multicolumn{5}{|c|}{ Posidonia australis } \\
\hline Sheaths & 7.8 & 5.4 & 6.3 & 258.6 \\
\hline Blades & 7.8 & 25.3 & 5.8 & 1115.2 \\
\hline Entire leaf & & & & 1373.8 \\
\hline Rhizomes & & & & 376.7 \\
\hline Total & & & & 1750.5 \\
\hline \multicolumn{5}{|c|}{ Posidonia coriacea } \\
\hline Sheaths & 5.6 & 9.6 & 4.7 & 252.7 \\
\hline Blades & 5.6 & 60.5 & 4.6 & 1558.5 \\
\hline Entire leaf & & & & 1811.2 \\
\hline Rhizomes & & & & 70.6 \\
\hline Total & & & & 1881.8 \\
\hline \multicolumn{5}{|c|}{ Posidonia sinuosa } \\
\hline Sheaths & 4.3 & 4.4 & 4.1 & 81.2 \\
\hline Blades & 4.3 & 40.2 & 3.3 & 597.0 \\
\hline Entire leaf & & & & 678.2 \\
\hline Rhizomes & & & & 204.9 \\
\hline Total & & & & 883.1 \\
\hline
\end{tabular}

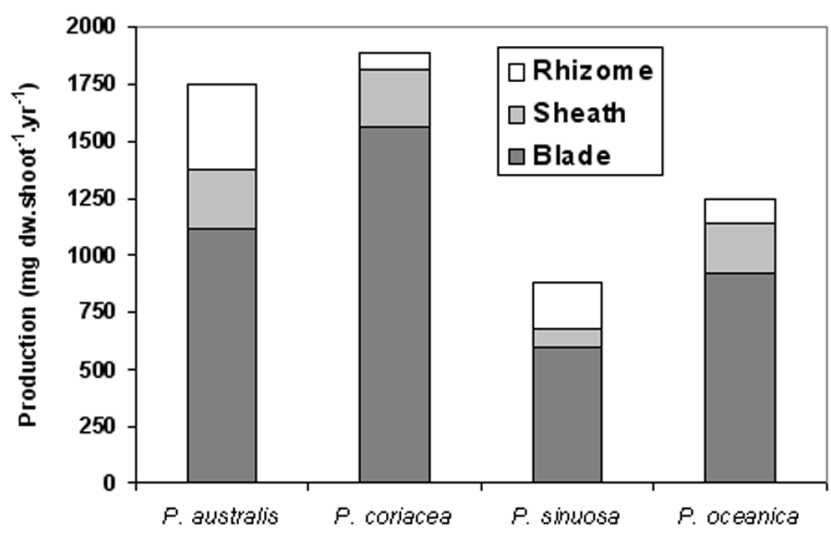

Figure 2. Primary production in four species of Posidonia (data for Posidonia oceanica from Pergent et al., 1997).

increases from a value of 5.0 in January to 10.0 in August, whereas the mean rank of the first maximum thickness for the same time period increases from 7.8 to 11.3. This represents a mean difference of 4.3 over a period of six months.

A regular alternation of long and short internodes along the rhizomes was also observed. As with the variations of thickness in the leaf sheaths, these cycles are synchronous and represent a comparable periodicity (Table 3). Several floral stalk remains were also found, inserted between dead sheaths, in Posidonia australis and Posidonia coriacea with a similar periodicity (Table 3 ).

Shoot production was highest in Posidonia coriacea and lowest in Posidonia sinuosa (Table 4). Rhizome production, which was estimated for the three species examined based on the mean weight of rhizome segments produced throughout the year, was lowest in Posidonia coriacea (Table 4; Figure 2).

\section{DISGUSSION AND CONGLUSION}

The decomposition of the sheaths once the blades have fallen varies from one species to another. Posidonia australis is the most interesting species with a good conservation of 25 to 30 dead sheaths along the rhizome (either 4 or 5 cycles), and considerable amplitude of leaf thickness. Although it is possible to measure the thickness between 10 and 20 sheaths in Posidonia sinuosa (3 to 5 cycles), the amplitude observed for this species, however, is much lower and the cycles are less regular. As for Posidonia coriacea, the rapid decomposition of the sheaths does not allow for more than one complete cycle of leaf thickness to be observed which limits research possibilities. The variability observed between shoots is generally very high for the above three species as compared with their Mediterranean counterpart (Pergent-Martini \& Pergent, 1995).

The preservation of sheaths in other locations should be checked, however, as the rate of decomposition can vary considerably depending on the characteristics of the sediment, the hydrodynamic conditions, the depth and the impact of detritivorous organisms. Taking extra care when sampling can increase the number of usable sheaths. As a result, in Posidonia oceanica the number of cycles that can be observed along the rhizomes can vary anywhere from 5 to 50 (in other words from 35 to 350 sheaths, in Pergent, 1987).

For the three species studied here, two additional chronological parameters can be considered: the internodal distance and the regular presence of floral stalk remains. Indeed, the alternation of long and short internodes along the rhizomes has already been noted in several species of marine phanerogams. This is usually a sign of seasonal growth variations directly related to environmental conditions (see review by Duarte et al., 1994). With Cymodocea nodosa, for example, the long internodes are formed in the 
spring whereas the short ones appear in the autumn and winter. Species of the genus Posidonia flower only once a year (Walker \& McComb, 1988), hence the presence of these floral stalks along the rhizomes is a strong chronological indicator. Although annual, this flowering only affects a portion of the shoots and not all shoots, however, flower each year. On the Australian species, regular flowering was only observed in Posidonia australis and Posidonia coriacea. In this study no flowers were found in Posidonia sinuosa (Table 3).

For Posidonia australis and Posidonia sinuosa, a comparison of the primary production values obtained here with those in the literature reveal that the results of the present study are consistent with those obtained using classical methods (Cambridge \& Hocking, 1997). No production estimates are available for Posidonia coriacea, most probably due to the depths at which it is found and the technical difficulties that ensue. Despite its deep bathymetric range (between 8 and $12 \mathrm{~m}$ in depth), foliar primary production in this species is very high, being in the order of $1800 \mathrm{mg} \mathrm{dw} \operatorname{shoot}^{-1} \mathrm{y}^{-1}$.

Primary production values obtained using lepidochronology take into account the sheath and blade. This is not the case for most classical methods, which only include the blade. In addition, the lepidochronology method also allows an estimation of rhizome production. Nevertheless, it should be noted that results obtained here are the result of an interpolation based on two samplings over a oneyear period and thus need to be further confirmed. Indeed, the sampling of Posidonia oceanica over a six month period generated an error factor between 5 and $18 \%$ according to the depth.

The three species of Australian Posidonia examined present a high primary sheath production. This is particularly true of Posidonia australis and Posidonia coriacea as these two species exhibit values which exceed those of the Mediterranean species, Posidonia oceanica (between 310 and $1540 \mathrm{mgdw} \operatorname{shoot}^{-1} \mathrm{y}^{-1}$ in Pergent-Martini et al., 1994). With the exception of $P$. coriacea, rhizome production is much higher in the Australian species (Figure 2).

Although the use of the lepidochronology method on Australian species of Posidonia brings with it a few technical difficulties, due in most part to the state of preservation of dead sheaths along the rhizomes, the results obtained are very encouraging and complementary studies should be undertaken, in particular using the size of internodes.

\section{REFERENCES}

Cambridge, M.L. \& Hocking, P.J., 1997. Annual primary production and nutrient dynamics of the seagrasses Posidonia sinuosa and Posidonia australis in south-western Australia. Aquatic Botany, 59, 277-295.
Crouzet, A., Boudouresque, C.F., Meinesz, A. \& Pergent, G., 1983. Evidence of the annual character of cyclic changes of Posidonia oceanica scale thickness (erect rhizomes). Rapports et Procès-verbaux des Réunions. Commission Internationale pour l'Exploration Scientifique de la Mer Méditerranée, 28, 113-114.

Duarte, C.M. et al., 1994. Reconstruction of seagrass dynamics - age determinations and associated tools for the seagrass ecologist. Marine Ecology Progress Series, 107, 195-209.

Duarte, C.M. \& Sand-Jensen, K., 1990. Seagrass colonization: patch formation and patch growth in Cymodocea nodosa. Marine Ecology Progress Series, 65, 183-191.

Giraud, G., 1979. Sur une méthode de mesure et de comptage des structures foliaires de Posidonia oceanica (Linnaeus) Delile. Bulletin Muséum Histoire Naturelle de Marseille, 39, 33-39.

Marbà, N., Gallegos, M.E., Merino, M. \& Duarte G.M., 1994. Vertical growth of Thalassia testudinum: seasonal and interannual variability. Aquatic Botany, 47, 1-11.

Olesen, B. \& Sand-Jensen, K., 1993. Seasonal acclimatization of eelgrass Zostera marina growth to light. Marine Ecology Progress Series, 94, 91-99.

Patriquin, D.G., 1973. Estimation of growth rate, production and age of the marine angiosperm Thalassia testudinum König. Caribbean Fournal of Science, 13, 111-121.

Pergent, G., 1987. Recherches Lépidochronologiques chez Posidonia oceanica (Potamogetonaceae). Fluctuations des paramètres anatomiques et morphologiques des écailles des rhizomes. $\mathrm{PhD}$ thesis, Univeristé de Aix-Marseille II, France.

Pergent, G., Boudouresque, C.F., Crouzet, A. \& Meinesz, A., 1989. Cyclic changes along Posidonia oceanica rhizomes (Lepidochronology): present state and perspectives. P.S.Z.N.I. Marine Ecology, 10, 221-230.

Pergent, G., Pergent-Martini, C. \& Cambridge, M., 1997. Morpho-chronological variations in the genus Posidonia. Australian Fournal of Marine Freshwater Research, 48, 421-424.

Pergent-Martini, C. \& Pergent, G., 1995. Lepidochronological analysis in the Mediterranean seagrass Posidonia oceanica: state of the art and future developments. Oceanologica Acta, 17, 673-681.

Pergent-Martini, C., Rico-Raimondino, V. \& Pergent, G., 1994. Primary production of Posidonia oceanica in the Mediterranean basin. Marine Biology, 120, 9-15.

Petersen, G.G.J., 1913. Om Baendeltangens (Zostera marina) Aarsproduktion i de danske Farvande. In Mindeskript Fapetus Steenstrups Fodsel, G.E.C. Gad (ed. H.F.E. Jungersen and E. Warning), 9, pp. 120. Copenhagen.

Walker, D.I. \& McComb, A.J., 1988. Seasonal variation in the productivity, biomass and nutrient status of Amphibolis antarctica and Posidonia australis in Shark Bay, Western Australia. Aquatic Botany, 31, 259-275. 